\title{
Empirical Study on Factors Affecting Biogas Production
}

\author{
Ravita D. Prasad \\ College of Engineering, Science, and Technology, Fiji National University, Suva, Fiji \\ Correspondence should be addressed to Ravita D. Prasad, prasad_ravita@yahoo.com
}

Received 10 April 2012; Accepted 19 June 2012

Academic Editors: R. S. Adhikari and S. S. Kalligeros

Copyright ( $) 2012$ Ravita D. Prasad. This is an open access article distributed under the Creative Commons Attribution License, which permits unrestricted use, distribution, and reproduction in any medium, provided the original work is properly cited.

\begin{abstract}
In Fiji, biogas has a huge potential to be one of the energy providers for cooking in rural areas but currently its use is very minimal. Main component of biogas is methane which releases energy when combusted. This paper mainly presents the factors that affect biogas production using experimental study. The first section presents an overview on what is biogas, types of biogas digesters present, and some background on the current use of biogas in Fiji. The second section of the paper describes the methodology in brief of the experimental work carried out. The third section of the paper presents results that were achieved in the experiment, discussion, and interpretation of the results and how Fiji could benefit from this study. It was evident that cow + Pig mix manure produces high rate of biogas at mesophilic temperature and cow dung manure is best for biogas production at room temperature.
\end{abstract}

\section{Introduction}

According to Prasad, in Fiji 70\% of total primary energy used comes from biomass and petroleum products [1]. Biogas which is part of biomass energy is used for cooking purpose in Fiji. However, its use is relatively small compared to energy providers such as petroleum products, electricity from diesel generators and hydro power systems, and butane gas (known as "Fiji gas"). Prasad also states that domestic cooking in rural areas in Fiji mainly uses mainly wood [1]. This, however, contributes to the health issues for women due to inhalation of smoke while cooking. Biogas is one of the alternative energy fuels to use for cooking. Arthur et al. argues that biogas is a clean fuel since it burns without leaving soot or particulate matter and it is lighter in terms of carbon chain length and, hence, less amount of carbon dioxide is released into the atmosphere during combustion [2]. According to Tudreu at Fiji Department of Energy, there are currently nine operational biogas plants in Fiji [3]. There are few biogas digesters which are already commissioned but the piping from digester to household is left to be done. Also, there are other biogas plants in some other areas but they are not operational now due to lack of knowledge in maintaining a digester, structural failure digesters, and lack of feedstock for daily input in digesters.
Anaerobic condition is needed for biogas production where methanogenic bacteria act on animal dung or plant waste. According to Energy Resources Development Series, biogas is composed of $50-70 \%$ methane $\left(\mathrm{CH}_{4}\right), 30-40 \%$ carbon dioxide $\left(\mathrm{CO}_{2}\right), 5-10 \%$ hydrogen $\left(\mathrm{H}_{2}\right), 1-2 \%$ nitrogen $\left(\mathrm{N}_{2}\right)$, and traces of water vapour and hydrogen sulphide $\left(\mathrm{H}_{2} \mathrm{~S}\right)$. There are three stages involved in methane production: (i) hydrolysis: this involves breaking down the large macromolecules to sugars, amino acids, and fatty acids by hydrolytic and fermentative bacteria under aerobic conditions, (ii) acetogenesis: during this stage the acetogenic bacteria convert sugars into short-chain acids, mainly acetic acid and (iii) methanogenesis: this stage is carried out by anaerobic bacteria where the acids are converted into methane [4-6].

To produce biogas, water is added to animal/plant waste in a certain ratio (this mixture is known as slurry) to optimize the biogas production and digestion takes place in an anaerobic digester. According to Sambo et al. temperature has significant effect on biogas production and temperature magnitude in excess of $60^{\circ} \mathrm{C}$ causes gas production to slow down and to eventually stop [7].

According to Erickson et al., the digester is an airtight tank which sometimes has heating coils and mechanical mixer [8]. The byproduct of methanogenic bacteria feeding 
on the animal/plant waste is biogas. As the gas is produced, it rises above the manure to the top of the digester where it is collected into the piping system. According to Vandeviviere et al., there are three simple types of biogas digesters: fixed dome, floating drums, and balloon plants [9].

The effluent from digesters can be used in farms as fertilizer which would consequently reduce the cost for purchase of fertilizers. The biogas produced can be used for heating and power generation purpose.

This paper will focus on the factors (such as temperature and type of animal/plant waste) affecting biogas yield in a model biogas digester. The methane content and energy content in biogas are also determined.

\section{Methodology}

Eleven 20-litre digesters were set up as shown in Figure 1. The digesters were as follows.

(i) At room temperature $\left(23-28^{\circ} \mathrm{C}\right)$-three different types of organic waste (cow, pig, and chicken) were used as input to three digesters.

(ii) At mesophilic temperature $\left(30-40^{\circ} \mathrm{C}\right)-6$ different types of organic waste (cow, pig, chicken, water hyacinth, vegetable (kitchen waste), and cow + pig mix (cow: pig $=7: 3$ ) were used as input to 6 digesters.

(iii) At thermophilic temperature $\left(50-60^{\circ} \mathrm{C}\right)$ - two organic wastes (cow and pig) were used as input in the two digesters.

Mesophilic and thermophilic temperatures were obtained by keeping the digester in enclosed cupboards with bulbs turned on to maintain the required temperature.

Organic waste was collected from Nausori, Montfort Boys Town, Ram Sami \& Sons Ltd., and market. Organic waste: water ratio was taken by mass as $1: 1$ for cow, pig, and cow + pig manure, while the waste: water ratio for chicken and kitchen waste was taken as $1: 2$ and for water hyacinth it was $1: 3$. The kitchen waste and water hyacinth were finely chopped to increase the surface area to volume ratio. The biogas was collected by downward displacement of water (Figure 1) and volume was recorded. This biogas was then passed through lime water to remove carbon dioxide and was lighted as shown in Figure 1(b). Horiba apparatus was used to find the methane content in the biogas.

\section{Experimental Results and Discussions}

3.1. Time It Took to Produce Burnable Gas. When the biogas produced from digesters was just plugged to Bunsen burner and lighted, the Bunsen burner did not light. To get successful results biogas was passed through lime water to remove the carbon dioxide. In the different digester models that were set up in this experiment, no effluent from existing digester was placed in the new digester. Hence, it took some time for methanogenic bacteria to develop in large numbers and produce biogas.
Considering Figure 2, pig manure at mesophilic temperature produces burnable gas in 7 days. The reason for this can be that initially there might be high percentage of $\mathrm{CO}_{2}$, $\mathrm{SO}_{2}, \mathrm{H}_{2} \mathrm{~S}$, and other gases present in biogas compared to the percentage of methane $\left(\mathrm{CH}_{4}\right)$.

At thermophilic temperature, the biogas from pig and cow manure produces burnable gas after 25 days of retention. The reason for this can be that thermophilic bacteria are very sensitive to temperature and for this experimental study thermophilic temperature ranged from $50-60^{\circ} \mathrm{C}$.

According to Gunnerson and Stuckey, temperature variations as small as $0.5^{\circ} \mathrm{C}$ in thermophilic digestion have adverse effects on biogas production [5]. Vindis et al. also says that in anaerobic digestion it is important that temperature remains constant [10]. Therefore, due to the variation in temperature the bacteria may not be able to survive in the changing environment. Moreover, cow and pig manure at room temperature produces burnable gas at significantly low time compared to other digester inputs in Figure 2.

\subsection{Effects of Temperature on the Amount of Biogas Collected.} Considering Figure 3(a), more biogas is produced from chicken manure at mesophilic temperature than chicken manure at room temperature. Also in view of Figure 2, chicken manure at room temperature produce burnable biogas after 24 days while chicken manure at mesophilic temperature produces burnable biogas after just 11 days. These two points imply that if chicken manure is to be used in biogas digesters then mesophilic temperature should be considered since the methanogenic bacteria production rate is good by looking at the amount of biogas produced and the time it took to produces burnable biogas.

Figure 3(b) shows the amount of biogas produced by cow dung as input in digester at three different temperatures. It is seen that biogas production at room temperature is slow for the first 10 days and then increased while at mesophilic temperature rate of production of biogas was slow and then it increased after 30 days. It is noted that at thermophilic temperature rate of production was almost constant and, in comparison with other two temperature graphs, the amount of biogas produced for the first 25 days was high. However, from Figure 2, it is known that this biogas did not burn until after 29 days. Cow dung at mesophilic temperature produced most biogas after 40 days. Hence, cow digester works best at mesophilic temperature.

In view of Figure $3(\mathrm{c})$, the biogas production from pig manure nearly stopped after 29 days from digester at room temperature and thermophilic temperature. For mesophilic digester, its rate of production of biogas kept increasing and also from Figure 2 it is seen that biogas from pig manure at mesophilic temperature started burning after 7 days. Therefore, pig manure is best for producing biogas at mesophilic temperature.

Overall, it is seen that as the temperature is increased the biogas production from all three different types of manure also increases. In addition, mesophilic temperature is best for biogas production for chicken manure, cow manure and, pig manure. 


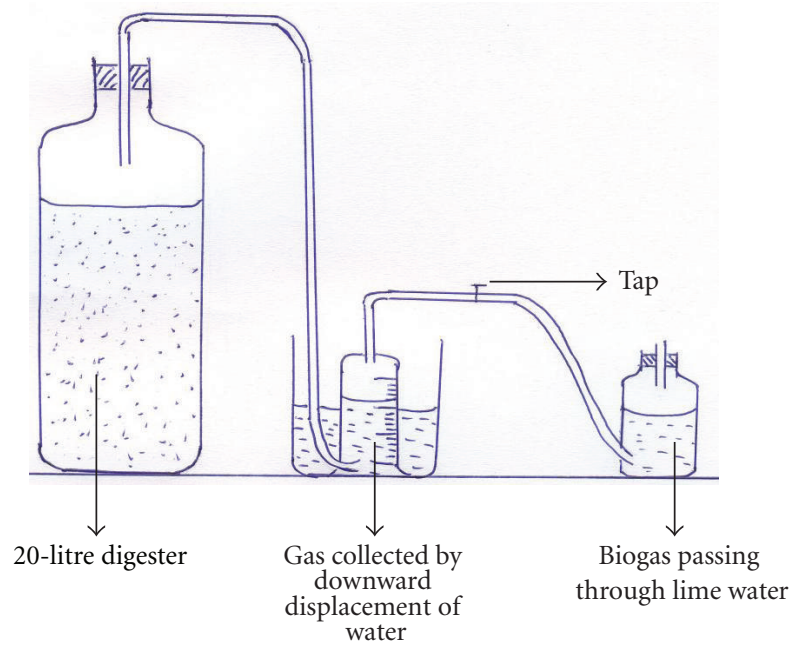

(a)
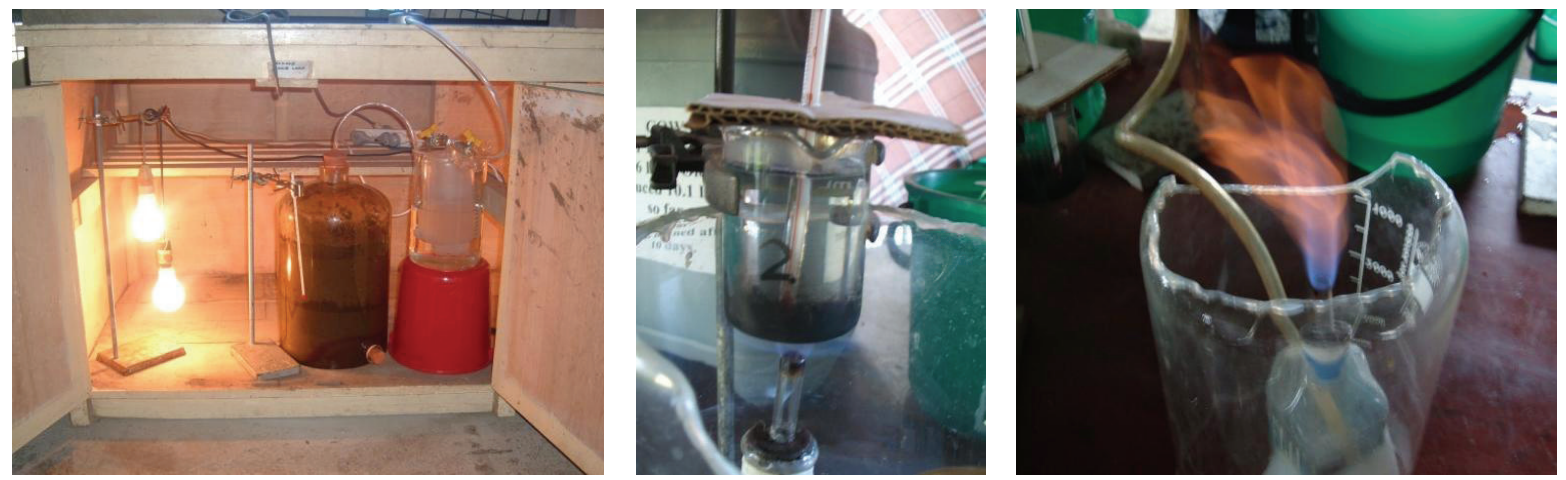

(b)

FIgURE 1: (a) Schematic diagram and (b) experimental setup.

\subsection{Effects of Plant/Animal Waste on Biogas Production.} Considering Figure 4(a), chicken manure has the largest biogas production at room temperature. However, from Figure 2, it is known that biogas produced from chicken at room temperature was not burning until 24 days passed. This could be due to the high $\mathrm{H}_{2} \mathrm{~S}$ present (this was detected by the rotten egg smell). Hence at room temperature, cow dung is appropriate for biogas production.

In view of Figure 4(b), cow manure at thermophilic temperature has more biogas production than pig manure. However, from Figure 2, cow and pig manure at thermophilic temperature produces burnable gas after 29 and 25 days respectively. This implies that methanogenic bacteria have to be introduced (from existing biogas digesters) in the digester from the beginning which would increase the chances of methane production early. Also [5] discusses that bacteria at thermophilic temperature are very sensitive to minute temperature changes. Hence, if there may have been slight temperature changes for thermophilic digesters during the experiment then survival of bacteria may have been limited.

Figure 4(c) shows the amount of biogas produced at mesophilic temperature from 6 different digesters. Chicken and cow + pig mix digester inputs were yielding high amount of biogas. From Figure 4(c), the best digester input at mesophilic temperature is cow + pig mix since it yields largest amount of biogas. Chicken manure yields largest amount of biogas for the first 30 days in comparison with other digester input. Furthermore, it is noted that cow + pig mix digester biogas production rate is slow in the first 15-20 days and then it increased. One of the reasons for this can be that since cow dung placed in digester was not that fresh it must have taken long time to dissolve and produce optimum biogas. Another reason can be that on 15th day the digester was shaken so this might have triggered trapped biogas in the digester to be released.

Moreover, at mesophilic temperature from Figure 4(c) it is seen that water hyacinth is producing more biogas than pig manure. However, after 30 days, biogas production was not much which implies that more water hyacinth has to be added to the digester. Vegetable (kitchen waste) is not producing very high amount of biogas and also from Figure 2 the biogas from kitchen waste digester did not burn until 26 days had passed. This could be due to a number of reasons. (i) The methanogenic bacteria might not be present in large numbers. (ii) Right amount of carbon and hydrogen molecules might not have been present, or (iii) the mixture may not have right amount of water added to it. 


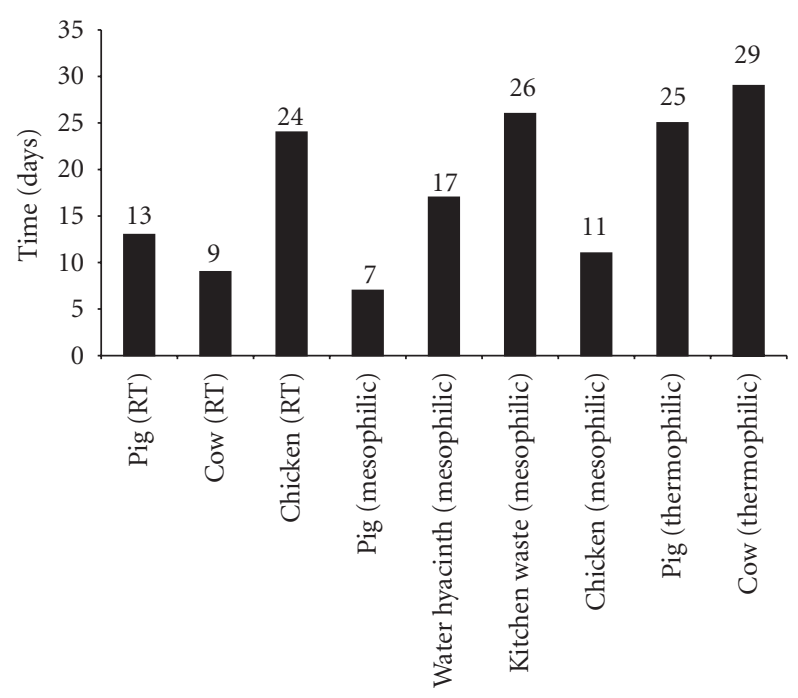

Digester input

Figure 2: Time before biogas burned from different digesters (Note: RT: room temperature $\left(23-28^{\circ} \mathrm{C}\right)$ ).

TABLE 1: Rate of biogas production.

\begin{tabular}{lcc}
\hline Temperature & Manure & Rate $(\mathrm{mL} / \mathrm{hr} /$ litre of digester $)$ \\
\hline \multirow{3}{*}{ Room $\left(23-28^{\circ} \mathrm{C}\right)$} & Chicken & 9 \\
& Cow & 3 \\
& Pig & 1 \\
\hline \multirow{5}{*}{ Mesophilic } & Pig & 2 \\
& Cow & 4 \\
& Cow + pig & 12 \\
& Water hyacinth & 2 \\
& Kitchen waste & 2 \\
& Chicken & 13 \\
\hline \multirow{2}{*}{ Thermophilic } & Cow & 3 \\
& Pig & 1 \\
\hline
\end{tabular}

3.4. Rate of Biogas Production. The rate of biogas production ( $\mathrm{mL} / \mathrm{hr} /$ litre of digester) was found for each digester on each day and then average of the rate was found, and the result is presented in Table 1.

This table very evidently shows that chicken manure and cow + pig mix manure have the highest rate of production of biogas at mesophilic temperature, which is between 12 to $13 \mathrm{~mL} / \mathrm{hr} /$ litre of digester. This means that if a 20-litre digester is made with input of cow + pig mix manure, then in one day there will be 5.76 litres of biogas and if this is projected to one year, then there will be 2104 litres $\left(2.1 \mathrm{~m}^{3}\right)$ of biogas produced. In Fiji, if it is assumed that on average a household with 5 members uses $13 l$ cylinder of gas for three months for cooking purposes, this would mean that if there is enough manure then biogas generated would be more than enough to supply 30 households for cooking.

Even chicken manure at room temperature has a high rate of biogas production. However, considering Figure 2, biogas from chicken manure at mesophilic temperature takes
TABLE 2: Energy content of biogas from different digesters.

\begin{tabular}{lccc}
\hline Temperature & Digester input & $\mathrm{EC}\left(\mathrm{Btu} / \mathrm{ft}^{3}\right)$ & $\mathrm{EC}\left(\mathrm{MJ} / \mathrm{m}^{3}\right)$ \\
\hline \multirow{3}{*}{ Room temperature } & Pig & 598.5 & 22.3 \\
& Cow & 591.2 & 22.0 \\
& Chicken & 543.9 & 20.3 \\
\hline \multirow{4}{*}{ Mesophilic } & Pig & 577.6 & 21.5 \\
& Water hyacinth & 616.7 & 23.0 \\
& Kitchen waste & 569.4 & 21.2 \\
& Chicken & 588.5 & 21.9 \\
\multirow{2}{*}{ Thermophilic } & Cow & 559.4 & 20.8 \\
& Cow + pig mix & 592.2 & 22.1 \\
\hline \multirow{2}{*}{ Average } & Pig & 588.5 & 21.9 \\
\hline
\end{tabular}

11 days to burn while at room temperature it takes 24 days to burn which implies that impurity is high in biogas from chicken manure. In the experiment, it was observed that biogas from chicken manure has "rotten egg" smell which indicates the presence of hydrogen sulphide. If the impurities can be removed from biogas before burning, then chicken manure would be a good input in digesters for biogas production at room temperature as well as at mesophilic temperature.

3.5. Percentage of Methane Present in Biogas. Horiba apparatus was used to find the percentage of methane present in the biogas produced once the biogas started to burn. This apparatus gave the percentage of nitrogen oxide (NO), sulfur dioxide $\left(\mathrm{SO}_{2}\right)$, carbon monoxide $(\mathrm{CO})$, carbon dioxide $\left(\mathrm{CO}_{2}\right)$, and oxygen $\left(\mathrm{O}_{2}\right)$ present in the biogas. The percentage of methane was found by subtracting all these percentages from $100 \%$.

In view of Figure 5, water hyacinth (mesophilic temperature) digester input produced most percentage of methane $(67.7 \%)$ compared to other digester inputs. Chicken manure at room temperature produced the lowest percentage of methane. It is also noted that all the digesters (except chicken at room temperature) had methane percentage more than $60 \%$.

3.6. Energy Content (EC) of Biogas. The energy content of biogas in $\mathrm{Btu} / \mathrm{ft}^{3}$ can be found from the lower heating value (LHV) of methane, since it is combustion of methane which produces heat energy;

$$
\mathrm{LHV}_{\text {biogas }}=\mathrm{LHV}_{\mathrm{CH}_{4}} \times \mathrm{F}_{\mathrm{CH}_{4}} \text {, }
$$

where $\mathrm{LHV}_{\mathrm{CH}_{4}}$ is $911 \mathrm{Btu} / \mathrm{ft}^{3}$ at standard conditions $15^{\circ} \mathrm{C}$ and $1 \mathrm{~atm}, \mathrm{~F}_{\mathrm{CH}_{4}}$ is fraction of methane in biogas.

Energy content of biogas from different digesters was found by using (1) and Figure 5. Table 2 summarizes these results. Overall, the average energy content of biogas comes to $21.6 \mathrm{MJ} / \mathrm{m}^{3}$ of biogas. 


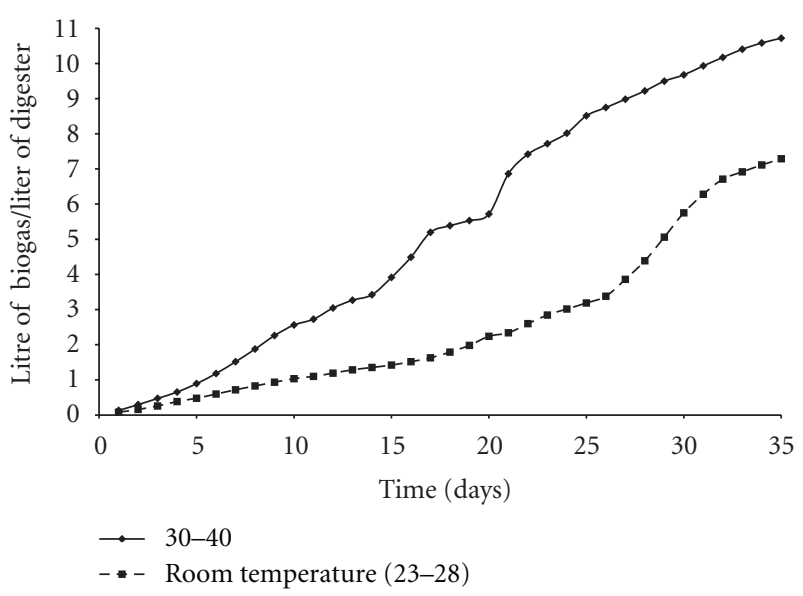

(a) Chicken manure

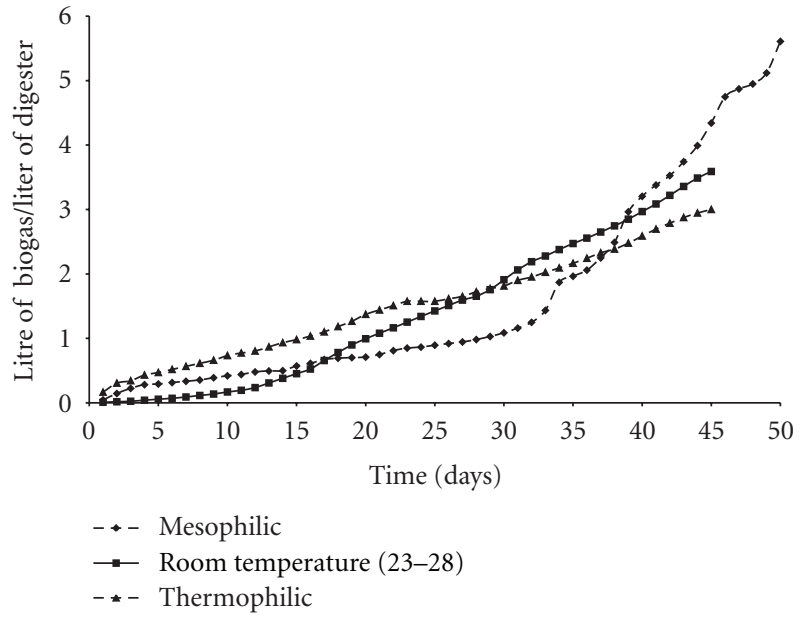

(b) Cow dung

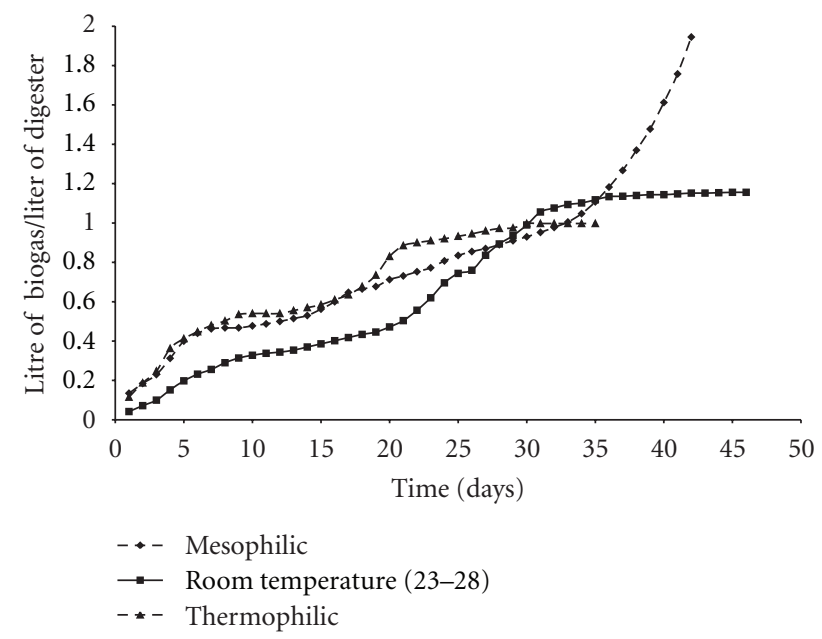

(c) Pig manure

Figure 3: Volume of biogas produced at different temperatures in Fiji.

3.7. Applying the Results to Biogas Use in Fiji. In Fiji, western and northern sides have warm temperatures on average 30$33^{\circ} \mathrm{C}$ while central and eastern sides have cool temperatures $23-30^{\circ} \mathrm{C}$. From the results, it has been found out that, with increase in temperature, the biogas yield also increases which implies that the western and northern division have good environmental conditions for biogas production. Specific feedstock that can be used in warmer regions in Fiji to produce biogas is pig + cow mix manure. In addition, chicken manure can be used for biogas production in the western side of the country.

Biogas digesters can be operational in rural areas where there is livestock resulting in dung readily available such as cattle, piggery, or poultry farms. This would lead to farmers getting biogas from dung as well as effluent from the digester can be used as fertilizers for crops.

Water hyacinth can also be used for biogas production as it has the highest methane percentage in its biogas (Figure 5). Since in some areas in Fiji, there are lots of water hyacinth and it can be a nuisance weed; this water hyacinth can be used in digester to solve the problem of weed as well as provide biogas for cooking.

It has to be mentioned at this point that for any biogas digester to be successful in its operation there must be ongoing maintenance of the digester. Also, occasional stirring of the digester will increase the rate of biogas production.

Thermophilic temperature digesters are not suitable to be used in rural areas in Fiji as it is expensive and high-energy input is needed to attain the high operating temperature of these digesters. The central and eastern division can use cow manure since its rate of production of biogas is high as well as it produces burnable biogas quickly and energy content is $22 \mathrm{MJ} / \mathrm{m}^{3}$.

\section{Conclusions and Recommendations}

Biogas is one of the energy providers in rural areas for cooking purposes. This paper attempted to determine which digester input would be better for digesters at different 


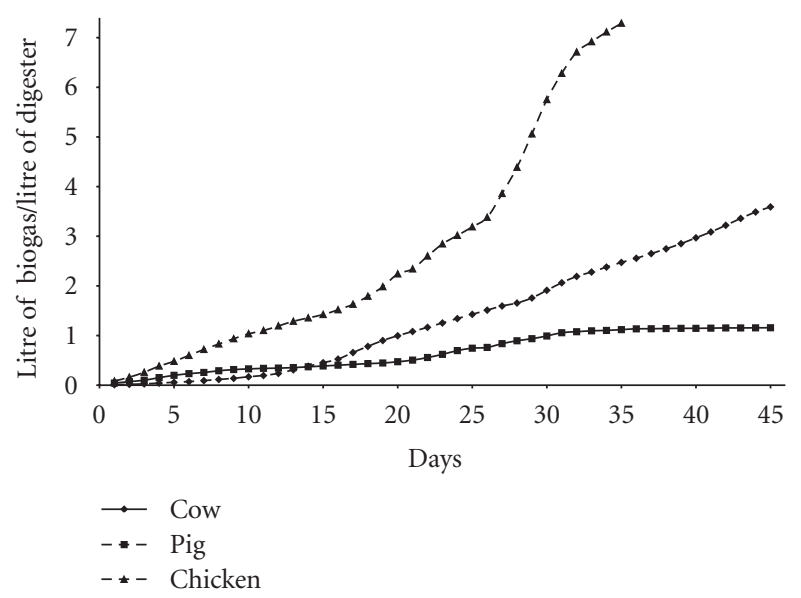

(a) Room temperature

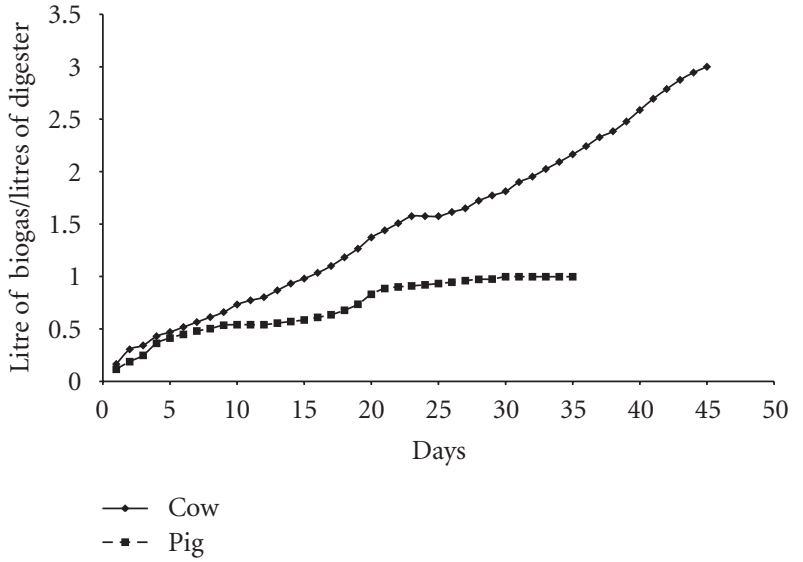

(b) Thermophilic temperature

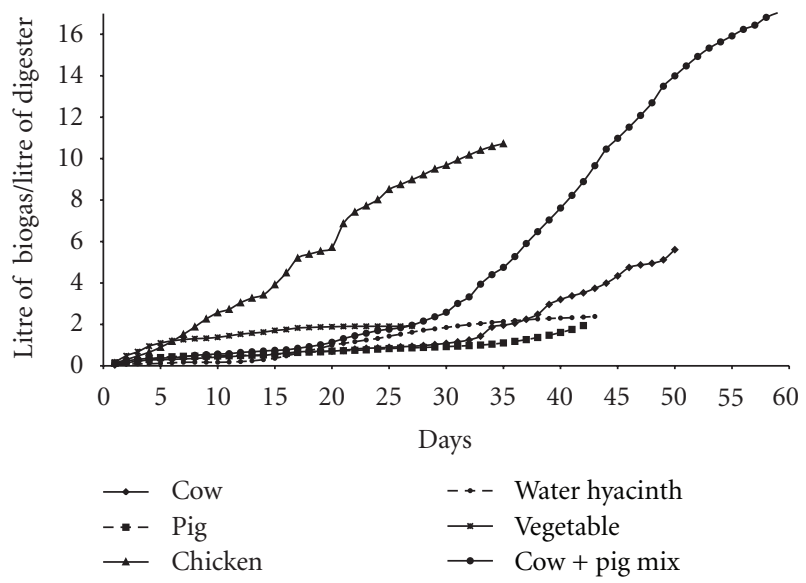

(c) Mesophilic temperature

FIgURE 4: Volume of biogas produced for different manure in Fiji.

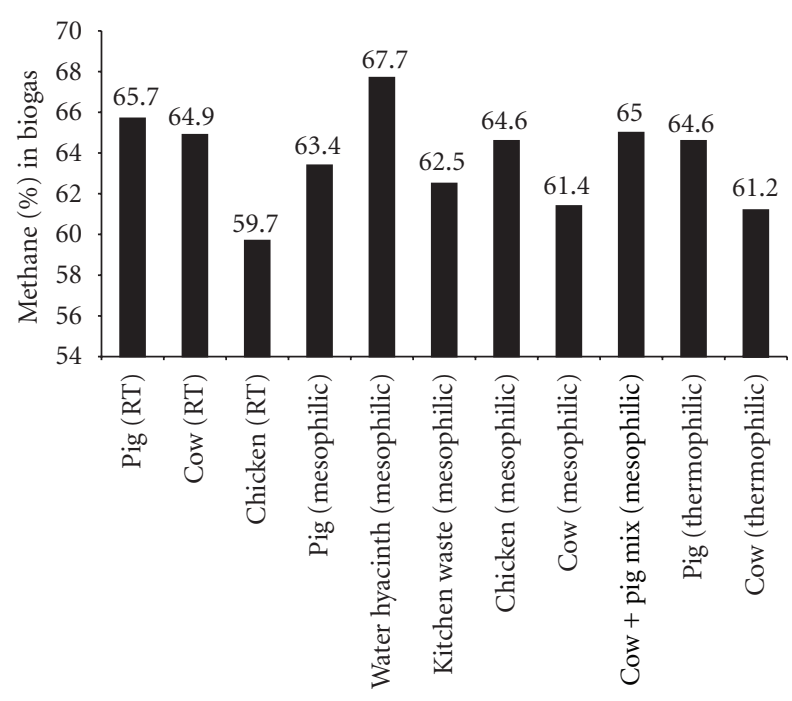

Digester input

temperatures. Digester having chicken manure at mesophilic temperature has high rate of biogas production. Also, cow + pig mix manure produces high rate of biogas production at mesophilic temperature. Thermophilic temperature digesters are not recommended for use in Fiji since they use high temperature which would increase the cost of production of biogas and also the biogas produced at this temperature started burning after approximately 25 days. Cow dung is best for input to digesters which are at room temperature. Also, occasional stirring of digesters would increase the rate of biogas production. For future studies in biogas, it is recommended that effluent from existing digesters be introduced in the beginning to observe the rate of biogas production. The effect of removing $\mathrm{H}_{2} \mathrm{~S}$ from biogas before burning can also be studied.

\section{Acknowledgments}

The author would like to thank Dr. S. Prasad for his support and guidance in this paper and Ms. S. Prescott for her contribution in this paper work. 


\section{References}

[1] S. Prasad, "Renewable energy resources and utilization in Fiji: An overview," http://www.insula.org/solar/proceedi49.htm.

[2] R. Arthur, M. F. Baidoo, and E. Antwi, "Biogas as a potential renewable energy source: a Ghanaian case study," Renewable Energy, vol. 36, no. 5, pp. 1510-1516, 2011.

[3] L. Tudreu, Fiji Department of Energy, Suva (Personal communication via email on 6th May 2011).

[4] Updated Guidebook on Biogas Development, vol. 27 of Energy Resources Development Series, United Nations, New York, NY, USA, 1984.

[5] C. G. Gunnerson and D. C. Stuckey, Anaerobic Digestion: Principles and Practices For Biogas Systems, The World Bank, Washington, DC, USA, 1986.

[6] M. A. Hessami, S. Christensen, and R. Gani, "Anaerobic digestion of household organic waste to produce biogas," in Proceedings of the World Renewable Energy Congress (WREC '96), pp. 954-957, 1996.

[7] A. S. Sambo, B. Garba, and B. G. Danshehu, "Effect of some operating parameters on biogas production rate," Renewable Energy, vol. 6, no. 3, pp. 343-344, 1995.

[8] L. E. Erickson, E. Fayet, B. K. Kakumanu, and L. C. Davis, "Anaerobic digestion," National Agricultural Biosecurity Center, Kansas State University, http://fss.k-state.edu/Featured Content/CarcassDisposal/PDF\%20Files/CH\%207\%20-\%20 Anaerobic\%20Digestion.pdf.

[9] P. Vandeviviere, L. De Baere, and W. Verstraete, "Types of anaerobic digester for solid wastes," in Biomethanization of the Organic Fraction of Municipal Solid Wastes, J. Mata-Alvarez, Ed., pp. 111-137, IWA Publishing, London, UK, 2002.

[10] P. Vindis, B. Mursec, M. Janzekovic, and G. Cus, "The impact of mesophilic and thermophilic anaerobic digestion on biogas production," Journal of Achievements in Materials and Manufacturing Engineering, vol. 36, no. 2, pp. 192-198, 2009, http://ww.journalamme.org/papers_vol36_2/36210.pdf. 

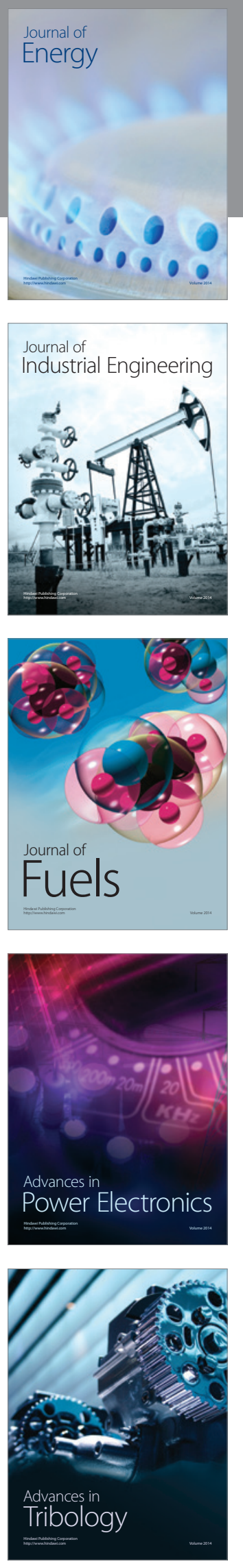
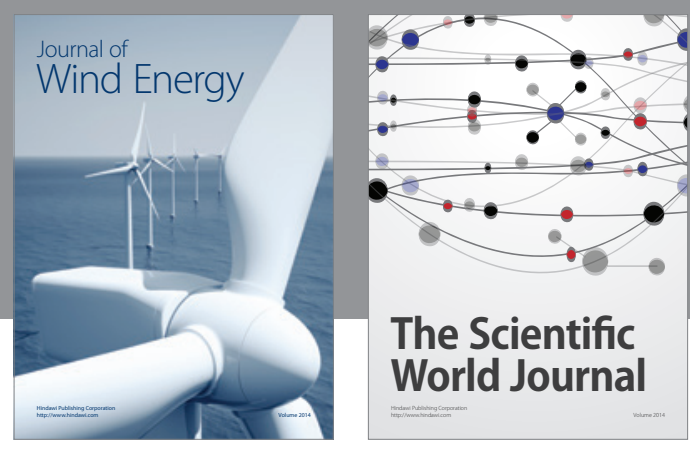

The Scientific World Journal

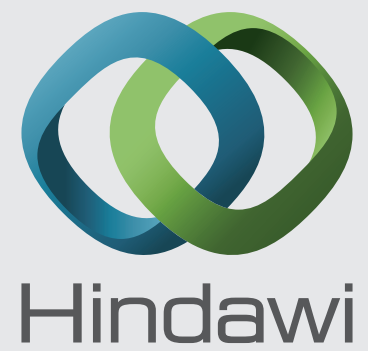

Submit your manuscripts at http://www.hindawi.com
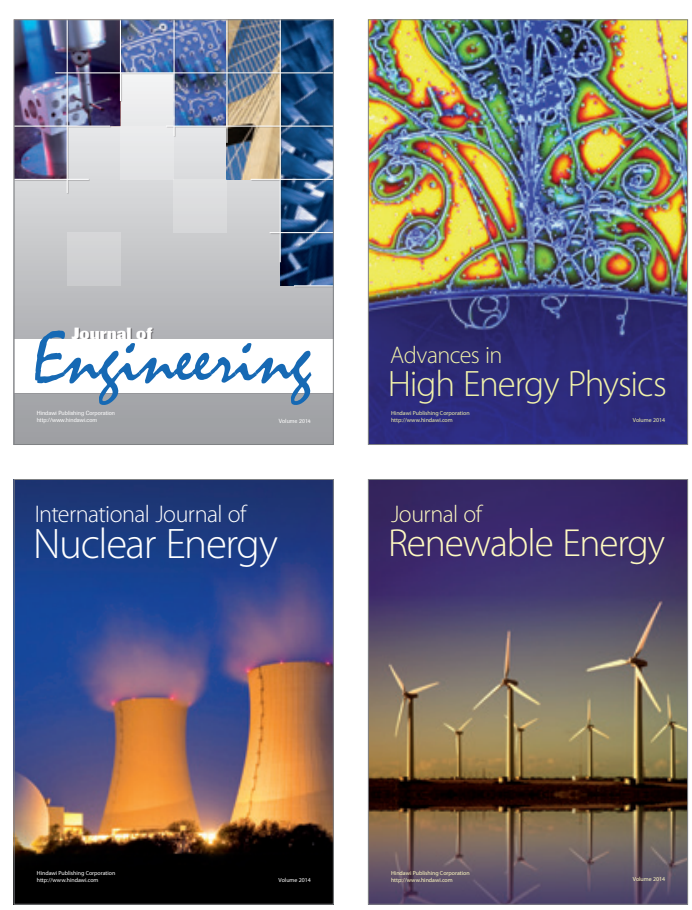

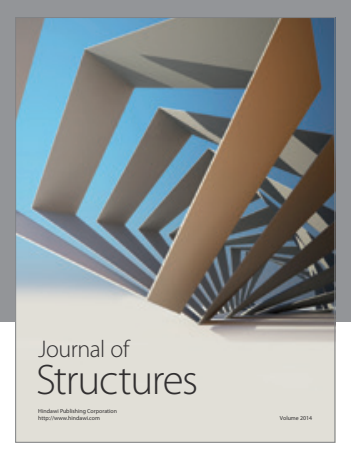

Rotating
Mechinery
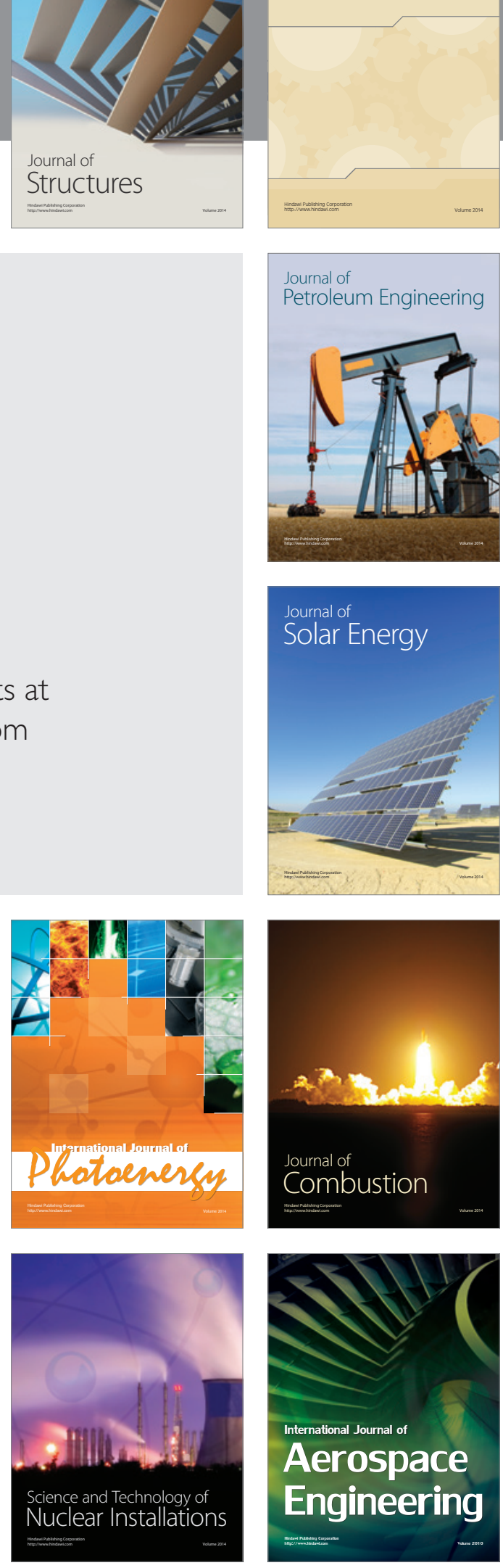